\title{
Authors' reply. Spotlight on measles 2010: Measles in healthcare workers - vaccination should be revisited
}

I Parent du Châtelet (i.parent@invs.sante.fr) ${ }^{1}$, D Floret ${ }^{2}$, J M Thiolet ${ }^{1}$, D Lévy-Bruhl ${ }^{1}$

1. Institut de Veille Sanitaire (InVS, French Institute for Public Health Surveillance), Saint-Maurice, France

2. Claude Bernard Lyon 1 University, French working group on measles and congenital rubella elimination, Lyon, France

Citation style for this article:

Parent du Châtelet I, Floret D, Thiolet JM, Lévy-Bruhl D. Authors' reply. Spotlight on measles 2010: Measles in healthcare workers - vaccination should be revisited. Euro Surveill. 2010;15(41):pii=19685. Available online: http://www.eurosurveillance.org/ViewArticle.aspx?Articleld=19685

Article published on 14 October 2010

To the editor: We thank Botelho-Nevers et al. for their interest in our paper [1] and for illustrating the risk for non-immune healthcare workers (HCWs) of contracting the disease in a context of high measles virus circulation in the community [2].

Since the beginning of the outbreak in 2008 and through the national early warning system [3], the French Institute for Public Health Surveillance (InVS) received a total of 42 notifications of nosocomial transmission events (three in 2008, 10 in 2009 and 29 since January 2010). Among the notified events, 30 involved at least one HCW, and 44 of 61 cases ( $72 \%$ ) were HCWs. Two of the three nosocomial transmission events in 2008 occurred in spite of a low prevalence of measles susceptibility in HCWs [4-7].

We agree with Botelho-Nevers et al. that due to the high contagiousness of measles, its control in healthcare settings can not rely only on barrier measures and that all efforts should be made to ensure that HCW are properly immunised. According to national recommendations, HCWs born in 1980 or later are targeted by the general catch-up immunisation strategy which consists in a single dose of measles-containing vaccine for all adults, HCW or not [8].

A control of measles serology among HCWs (in position as well as students or applicants) born before 1980 without a reliable history of measles or vaccination is recommended and vaccination should be proposed in case of a negative result. Mandatory measles serology for hospital staff would certainly increase the knowledge of HCWs of their immune status for measles. However recruiting only immunised $\mathrm{HCWs}$ for at-risk medical wards would be very difficult to implement in the current context of staff shortage, and quite impossible for medical students.

Our data confirm the insufficient implementation of current recommendations issued by the French health authorities and therefore the difficulty in preventing measles in healthcare settings. However, this difficulty is partly offset by the recommendation,to administrate immediately after a contact with a confirmed measles case one dose of measles-mumps-rubella (MMR) vaccine to HCWs who were not previously vaccinated with two doses of MMR vaccine or who can not provide a serological proof of immunity.

It would be helpful to identify the reason behind the low compliance of healthcare professionals regarding the knowledge of their serological status and/or the updating of their vaccination status. Ongoing efforts to sensitize HCWs regarding the risk of transmission from pre-symptomatic contagious HCWs measles cases to severe measles at-risk patients (e.g. immunocompromized patients) should be maintained.

\section{References}

1. Parent du Châtelet I, Antona D, Freymuth F, Muscat M, Halftermeyer-Zhou F, Maine C et al. Spotlight on measles 2010: Update on the ongoing measles outbreak in France, 2008-2010. Euro Surveill. 2010;15(36):pii=19656. Available from: http:// www.eurosurveillance.org/ViewArticle.aspx?Articleld $=19656$

2. Botelho-Nevers E, Chevereau L, Brouqui P. Letter. Spotlight on measles 2010: Measles in healthcare workers - vaccination should be revisited. Euro Surveill. 2010;15(41):pii=19687. Available from: http://www.eurosurveillance.org/ViewArticle. aspx?Articleld $=19687$

3. The RAISIN Working Group. "RAISIN" - a national programme for early warning, investigation and surveillance of healthcare-associated infection in France. Euro Surveill. 2009;14(46): pii=19408. Available from: http://www. eurosurveillance.org/ViewArticle.aspx?Articleld=19408

4. Sillam F, Cua E, Faudeux D, Peloux-Petiot F, Negre A, Six $C$, et al. Investigation d'une épidémie de rougeole avec transmissions nosocomiales en région Provence-Alpes-Côte d’Azur et dans la Principauté de Monaco, mars - mai 2008. Quels enseignements en tirer? [Investigation of a measles outbreak with nosocomial transmission in Provence-Alpes-Côte d'Azur and in the Principality of Monaco, March-May 2008. What are the lessons learned?]. [French.] Bull Epidemiol Heb. 2009;39-40:424-6. Available from: http://www.invs.sante.fr/ beh/2009/39_40/beh_39_40_2009.pdf

5. Bureau-Chalot A, Brodard V, Oud N, Touche S, Bajolet O, Abely $M$, et al. [Gestion d'une épidémie hospitalo-communautaire de rougeole au CHU de Reims, janvier-mars 2008. [Management of a hospital/community measles outbreak at the Reims University Hospital, January-March 2008]. [French]. Bull Epidemiol Heb. 2009;39-40:427-9. Available from http://www. invs.sante.fr/beh/2009/39_40/beh_39_40_2009.pdf

6. Thierry S, Alsibai S, Parent du Chatelet I, on behalf of the investigation team. An outbreak of measles in Reims, eastern France, January-March 2008--a preliminary report. Euro Surveill. 2008;13(13): pii=8078. Available from: http://www. eurosurveillance.org/ViewArticle.aspx?Articleld $=8078$ 
7. Touche S, Delavelle AC, Lundu B, Brodard V, Lévêque N.

Rougeole au CHU de Reims en 2008 : statut immunitaire des

soignants. [Measles in a teaching hospital in Reims, France,

in 2008: immune status of health care workers]. [French]. Bull Epidemiol Heb. 2009;39-40:430-2. Available from http://www. invs.sante.fr/beh/2009/39_40/beh_39_40_2009.pdf

8. French Ministry of Health and Sports. CIRCULAIRE $N^{\circ} D G S /$

$\mathrm{Rl} 1 / 2009 / 334$ du 4 novembre 2009 relative à la transmission obligatoire de données individuelles à l'autorité sanitaire

en cas de rougeole et la mise en oeuvre de mesures

préventives autour d'un cas ou de cas groupés. [Circular No.

DGS/RI1/2009/334 of 4 November 2009 on the mandatory

notification of individual data to the health authority in case of

measles and implementation of preventive measures around a case or a cluster]. [French]. Available from: http://www.santesports.gouv.fr/IMG/pdf/o9_334topdf.pdf 